Original Research Paper

\title{
Peningkatan Penguasaan Kosakata Noun melalui Model See, Talk, Write dan Media Gambar Pada Peserta Didik Kelas 7D SMPN 2 Pasuruan
}

\author{
Nur Rochmah ${ }^{1}$ \\ 1Sekolah Menengah Pertama Negeri 2 Pasuruan, Kota Pasuruan, Jawa Timur, Indonesia.
}

*Corresponding Author:

Nur Rochmah, Sekolah

Menengah Pertama Negeri 2

Pasuruan, Kota Pasuruan,

Jawa Timur, Indonesia

Email:

Nrochmah345@gmail.com

\begin{abstract}
Abstrak: Menurut kurikulum 13 pada mata pelajaran Bahasa Inggris, menulis dan membaca merupakan keterampilan yang harus dikuasai oleh peserta didik selain mendengarkan dan berbicara. Bagi peserta didik di tingkat SMP kelas VII mengenal Kosakata adalah sangat penting karena dengan mengenal banyak kosakata maka belajar Bahasa Inggris menjadi sangat mudah dan menyenangkan. Untuk mempermudah menguasai kosakata Bahasa Inggris terutaman bentuk noun, penulis menggunakan model pembelajaran STW (See, Talk, and Write). Penelitian model pembelajaran STW ini diterapkan pada peserta didik kelas 7D SMPN 2 Pasuruan dan dilaksanakan dalam dua siklus. Masing-masing siklus terdiri dari Perencanaan, Pelaksanaan, Pengamatan dan Refleksi. Hasil penilaian menggunakan model pembelajaran STW menunjukkan bahwa pada siklus pertama, banyak siswa yang memiliki nilai di atas KKM adalah 17 dari 34 peserta didik (50\%). Sedangkan pada siklus kedua, siswa yang memiliki nilai di atas KKM sebanyak 28 dari 34 Peserta didik (82\%). Hal ini menunjukkan peningkatan secara signifikan sebesar $32 \%$. Dengan demikian dapat disimpulkan bahwa Model Pembelajaran STW (See, Talk, and Write) dapat meningkatkan penguasaan kosakata bentuk noun pada peserta didik kelas 7D SMPN2 Pasuruan.
\end{abstract}

Kata Kunci: Penguasaan; Kosakata Noun; STW; Media Gambar

\section{Pendahuluan}

Bahasa Inggris merupakan Bahasa yang disepakati dunia untuk dijadikan Bahasa Internasional Bahasa asing yang banyak digunakan sebagai alat komunikasi di berbagai negara, salah satunya Indonesia. Berdasarkan sistem pendidikan di Indonesia, Bahasa Inggris diajarkan sejak di tingkat sekolah dasar. Terdapat empat kompetensi yang harus dikuasai peserta didik dalam belajar Bahasa Inggris, yaitu mendengar (listening), berbicara (speaking), membaca (reading), dan menulis (writing). Untuk menguasai keempat kompetensi tersebut dengan baik, peserta didik harus terlebih dahulu belajar mengenai kosakata (vocabulary). Menurut Thornburry (2002 dalam Rohman, 2016) mempelajari kosakata merupakan salah satu hal yang penting ketika mempelajari Bahasa Inggris, karena tanpa mengetahui kosakata, peserta didik tidak akan mengatahui apapun dari Bahasa Inggris.

Mata pelajaran Bahasa Inggris merupakan salah satu mata pelajaran memiliki keunikan dan karakter yang berbeda dengan mata pelajaran yang lain. Keunikan tersebut 
tampak dari perbedaan antara ucapan dengan tulisan suatu kosakata.

Menurut kamus Merriam-webster.com kosakata adalah kumpulan kata-kata yang memiliki makna tertentu. Sedangkan menurut Rohman (2016) kosakata adalah kumpulan kata yang memiliki makna dan merupakan komponen penting dalam mempelajari bahasa.

Namun peserta didik di kelas 7D SMPN 2 Pasuruan mengalami kesulitan dalam menguasai kosakata dalam Bahasa Inggris. Kesulitan yang dimaksud adalah tidak dapat menyebutkan nama-nama benda di lingkungan sekolah dengan pengucapan yang tepat. Sebagai contoh, dari 34 peserta didik hanya 10 yang dapat menyebutkan namanama benda dengan baik dan benar. Sisanya sibuk mencari di kamus, bertanya kepada temannya dan bahkan ada yang enggan untuk mendengarkan serta menjawab pertanyaanpertanyaan yang dilontarkan oleh guru. Terdapat pula kasus ketika guru menyuruh salah satu peserta didik untuk menyebutkan nama benda dalam Bahasa Inggris dan pada saat menyebutkannya kurang tepat, maka peserta didik yang lain mentertawakannya, hal ini menyebabkan peserta didik tersebut malu dan menjadi enggan untuk mencoba kembali.

Kesulitan tersebut disebabkan beberapa hal yaitu, peserta didik berasal dari sekolah dasar yang tidak pernah mengajarkan mata pelajaran Bahasa Inggris, peserta didik yang bersangkutan merasa sudah lupa atau pada saat diberi materi tersebut mereka kurang memperhatikan, peserta didik menganggap bahwa mata pelajaran Bahasa Inggris ini tidak penting dan justru menjadi pelajaran yang sulit dan tidak menarik, banyak siswa yang enggan untuk memanfaatkan kamus yang sudah disediakan oleh perpustakaan sekolah, dan faktor internal siswa yang malas untuk membaca kamus meskipun sudah difasilitasi oleh orang tua.

Selain itu keberagaman kemampuan dalam menyebutkan nama-nama benda dalam Bahasa Inggris ini membuat suasana kelas menjadi sangat tidak kondusif. Bagi siswa yang sudah mampu, ingin segera meminta untuk menambah kosakata yang diberikan guru, sedang yang kurang mampu menjadi kebingungan dan bahkan yang tidak berminat justru mengganggu teman yang lainnya. Latar belakang sekolah dasar yang berbeda, minat yang rendah, kurangnya motivasi dan ketidakseriusan dalam mengikuti pelajaran Bahasa Inggris ini merupakan masalah besar bagi guru pengajar. Padahal mata pelajaran Bahasa Inggris di SMP merupakan salah satu mata pelajaran yang masuk dalan Ujian Nasional.

Sebelum dilakukan penelitian tindakan kelas, pembelajaran Bahasa Inggris dilakukan dengan cara lama. Pertama guru memberikan penjelasan kepada peserta didik kemudian menyuruh mereka untuk menjawab pertanyaan. Cara ini menyebabkan peserta didik merasa bosan sehingga memerlukan metode pengajaran yang baru.

Hambatan di atas perlu untuk diselesaikan dengan mengubah metode pembelajaran supaya peserta didik menjadi mampu menguasai kosakata (vocabulary) dengan mudah tanpa harus merasa bosan.

Penulis mengusulkan model pembelajaran STW (See, Talk, Write) sebagai bentuk intervensi untuk mempermudah peserta didik menguasai kosakata dalam Bahasa Inggris.

Model pembelajaran STW adalah modifikasi dari model pembelajaran TTW (Think, Talk, and Write). Umumnya aktivitas berpikir (think) pada model TTW diawali dengan membaca teks sehingga dari membaca peserta didik secara bersamaan telah berdialog dengan dirinya sendiri (Farkhana, 2016). Namun menurut Yussa (2012) media gambar lebih efisien dan mudah jika digunakan untuk mengajarkan kosakata Bahasa Inggris dalam pembelajaran karena dengan melihat gambar peserta didik dapat mengaitkannya dengan peristiwa yang terjadi di kehidupan mereka sehari-hari. 
Bukti tersebut juga didukung oleh hasil dari beberapa penelitian yang membuktikan bahwa media gambar membantu siswa dalam memahami objek yang baru dikenal sehingga dari proses melihat mereka mampu mengimajinasikan gambar menjadi lebih efisien dan efektif (Fauziah, 2011).

Berdasarkan bukti di atas, penulis berasumsi bahwa dengan melihat (see) gambar, peserta lebih mudah untuk menguasai kosakata dalam Bahasa Inggris daripada ketika berpikir (think) dari membaca teks. Maka model pembelajaran pada penelitian ini disebut dengan see, talk, write.

\section{Metode}

\section{A. Tempat Penelitian}

Penelitian ini dilaksanakan di SMP Negeri 2 Pasuruan yang berlokasi di Jl. Soekarno Hatta No.84, Bangilan, Panggungrejo, Kota Pasuruan, Jawa Timur.

Secara keseluruhan, waktu penelitian dilaksanakan mulai bulan 18 September 2017 sampai dengan 16 Oktober 2017. Subjek dalam penelitian tindakan kelas ini adalah siswa kelas 7D yang berjumlah 34 siswa, yang terdiri dari 17 laki-laki dan 17 perempuan.

\section{B. Jenis Penelitian}

Jenis penelitian yang digunakan adalah Peneltian Tindakan Kelas (PTK) dengan melakukan modifikasi pada model pembelajaran TTW (Think, Talk, Write). Penulis mengganti aktivitas berpikir (think) dengan aktivitas melihat (see) media gambar untuk memudahkan peserta didik dalam menguasai kosakata Noun.

Umumnya aktivitas berpikir (think) pada model TTW diawali dengan membaca teks sehingga dari membaca peserta didik secara bersamaan telah berdialog dengan dirinya sendiri (Farkhana, 2016). Namun menurut Yussa (2012) media gambar lebih efisien dan mudah jika digunakan untuk mengajarkan kosakata Bahasa Inggris dalam pembelajaran karena dengan melihat gambar peserta didik dapat mengaitkannya dengan peristiwa yang terjadi di kehidupan mereka sehari-hari.

Penelitian tindakan kelas adalah salah satu strategi yang digunakan untuk menyelesaikan permasalahan di dalam kelas dengan memberikan intervensi pada metode pembelajaran (Narmaditya dkk., 2017).

Rencana tindakan ini dibagi menjadi 2 siklus yang masing-masing siklus terdiri dari 4 tahap perencanaan, pelaksanaan, pengamatan, dan refleksi.

1. Tahap perencanaan adalah guru menyiapkan kosakata benda dari video dan buku Bahasa Inggris When English Rings a Bell kelas 7.

2. Tahap Pelaksanaan

a. Guru menyuruh peserta didik mengamati kosakata noun yang di tayangkan dalam video.

b. Peserta didik menyebutkan kosakata tersebut dengan menggunakan artikel $a$ dan an serta there is dan there are.

c. Guru meminta peserta didik menuliskannya di papan tulis

3. Tahap pengamatan adalah tahap ketika guru selaku peneliti mencatat segala hal yang terjadi baik positif maupun negatif selama berlangsungnya proses kegiatan.

4. Tahap refleksi adalah tahap ketika guru mengevaluasi hasil pengamatan untuk menemukan masalah yang terjadi selama proses kegiatan berlangsung. Hasil refleksi ini juga digunakan untuk menentukan langkah perbaikan pada pelaksanaan siklus berikutnya.

\section{Rencana Tindakan}

Rencana tindakan Penelitian ini mengacu pada kompetensi dasar (KD) 3.4: Mengidentifikasi fungsi sosial, struktur teks, dan unsur kebahasaan teks interaksi transaksional lisan dan tulis yang melibatkan tindakan memberi dan meminta informasi terkait nama dan jumlah binatang, benda, dan bangunan publik yang dekat dengan 
kehidupan peserta didik sehari-hari sesuai dengan konteks penggunaanya.

Sehingga, indikator pencapaian yang diharapakan dari penelitian ini adalah:

1. Peserta didik mampu mengidentifikasi fungsi sosial dari teks untuk menyatakan dan menanyakan tentang nama dan jumlah benda-benda tunggal dan bendabenda jamak dengan di sekitar mereka menggunakan artikel $a$ dan an serta there is dan there are.

2. Peserta didik mampu mengidentifikasi struktur teks untuk menyatakan dan menanyakan tentang nama dan jumlah benda-benda tunggal dan benda-benda jamak di sekitar mereka dengan menggunakan artikel $a$ dan an serta there is dan there are.

3. Peserta didik mampu mengidentifikasi unsur kebahasaan dari teks untuk menyatakan dan menanyakan tentang nama dan jumlah benda-benda tunggal dan jamak di sekitar mereka dengan menggunakan artikel $a$ dan an serta there is dan there are.

\section{Teknik Pengumpulan Data}

Data dikumpulkan melalui tes tertulis di akhir pembelajaran untuk mengetahui seberapa banyak kosakata yang berhasil ditulis oleh peserta didik dari melihat tayangan video.

\section{Hasil dan Pembahasan}

\section{A. Siklus 1}

1. Perencanaan

Perencanaan awal yang di buat oleh penulis adalah sebagai berikut:

a. Guru menyampaikan tujuan pembelajaran kepada peserta didik.

b. Guru memutar video materi tentang things around us (benda-benda di sekitar kita) baik yang berbentuk tunggal maupun jamak.

c. Guru membagi kelas menjadi beberapa kelompok, tiap kelompok terdiri dari 5 atau 6 peserta didik.
2. Pelaksanaan

a. Guru meminta peserta didik untuk bertanya seputar tayangan video tentang koskata benda berbentuk tunggal dan kosakata benda berbentuk jamak.

b. Setiap kelompok di minta mengamati gambar yang sudah di tayangkan kemudian diminta menyebutkan nama nama benda tersebut.

[1] What things do you find in the living room?

[2] What things do you find in the dining room?

[3] What things do you find in bedroom?

[4] What things do you find in the kitchen?

[5] What things do you find in the classroom?

c. Guru memberi contoh cara menyebutkan kosakata benda berbentuk tunggal dan kosakata benda berbentuk jamak dengan menggunakan artikel $a$, an there is dan there are.

d. Setiap kelompok menyebutkan secara bergantian kosakata benda berbentuk tunggal dan kosakata benda berbentuk jamak dengan menggunakan artikel a, an, there is and there are.

e. Setiap peserta didik di beri kesempatan untuk menyebutkan nama-nama benda.

f. Guru membantu membetulkan apabila terdapat kesalahan dalam pengucapan yang dilakukan oleh peserta didik.Guru meminta setiap kelompok menuliskan kosakata benda berbentuk tunggal dan kosakata benda berbentuk jamak yang mereka sebutkan.

c. Guru mengadakan tes tertulis untuk mengetahui seberapa banyak penguasaan kosakata noun yang di miliki peserta didik.

\section{Pengamatan}

Pada saat pelaksanaan siklus 1 ini masih banyak peserta didik melakukan kesalahan dalam menyebutkan kosakata benda dengan menggunakan artikel $a$, an, there is an there are. Peserta didik masih banyak bergurau dan tidak sungguh-sungguh dalam menyebutkan 
gambar yang di perlihatkan melalui tayanagan video. Hal ini mengakibatkan kelas menjadi ramai oleh teriakan dan ocehan meraka. Peserta didik saling membantah atas kesalahan ucapan maupun tulisan temanya. Banyak yang tertawa karena melihat temannya mengucapkan nama benda-benda itu dengan pronounciation yang kurang tepat, terutama bila peserta didik di suruh menyebutkan nama benda secara individu. Dialek madura yang kental menambah suasana belajar menjadi tidak kondusif. Pada siklus 1 nilai di atas KKM sebanyak 17 dari 34 peserta didik atau sebesar $(50 \%)$ diambil pada pelaksanaan tes tulis.

Tabel 1. Hasil pre-test

\begin{tabular}{lll}
\hline Jumlah Siswa & $\begin{array}{l}\text { Di bawah } \\
\text { KKM }\end{array}$ & Di atas KKM \\
\hline 34 & 17 & 17 \\
\hline${ }^{*}$ Nilai KKM $=70$ & &
\end{tabular}

4. Refleksi

Dari hasil pengamatan yang dilakukan pada pelaksanaan siklus I penulis mencatat beberapa temuan sebagai berikut:

a. Peserta didik tampak banyak yang belum aktif mengikuti kegiatan pembelajaran.

b. Peserta didik belum dapat berkonsentrasi pada gambar yang di tunjukkan oleh guru melalui tayangan video.

c. Peserta didik masih banyak kesalahan dalam pengucapan ketika disuruh mengucapkan secara individu.

d. Meski belajar secara berkelompok masih banyak yang tidak serius selama pembelajaran.

e. Suasana kelas menjadi kurang kondusif sehingga guru harus mengingatkan pada setiap kelompok untuk lebih serius.

f. Hasil pembelajaran tentang penguasaan kosakata noun dengan artikel a, an, there is dan there are kurang memuaskan.

\section{B. Siklus II}

1. Perencanaan.

Dari hasil pelaksanaan siklus 1 maka penulis mengadakan perbaikan pada Perencanaan sebagai berikut: a. Guru membagi kelas menjadi 5 kelompok yang terdiri dari 6 atau 7 peserta didik.

b. Setiap kelompok di beri kesempatan untuk berkreasi membuat alat peraga sesuai dengan tema masing-masing.

c. Alat peraga yang harus disiapkan oleh peserta didik ada 2 macam, yang pertama gambar benda-benda tersebut ditempel di kertas manila dan diberi keterangan pada tiap-tiap bendanya. Yang kedua masih dengan benda yang sama tanpa keterangan dalam bentuk card untuk kuis tebak gambar.

d. Peserta didik diberi batasan waktu satu minggu $(2 \times$ pertemuan) untuk membuat alat peraga.

\section{Pelaksanaan}

a. Guru mengumpulkan setiap ketua kelompok untuk diberi arahan tentang tahapan selama pembelajaran.

b. Tahap awal ketua kelompok membuka pembelajaran STW dengan memberi salam dan memperlihatkan gambar benda-benda yang dipajang untuk diamati anggotanya.

c. Ketua kelompok menyebutkan gambar benda-benda tersebut satu-persatu dengan ucapan yang benar dan diikuti oleh anggotanya. Apabila ketua kelompok salah dalam pengucapan maka teman lainnya atau guru membantu membenarkan. Sampai semua benda-benda yang diucapkan tidak ada yang salah.

d. Setiap anggota dari kelompok tersebut mengulang kembali menyebutkan bendabenda yang ditunjuk oleh ketua kelompok.

e. Pada saat sesi kuis, gambar yang tertempel di manila ditutup. Ketua kelompok menunjukkan kartu gambar tanpa keterangan untuk disebutkan oleh anggotanya secara bergiliran.

f. Ketua kelompok membagikan potongan kertas untuk ditulis nama-nama benda yang sudah disebutkan.

g. Ketua kelompok bersama anggota mengoreksi pekerjaan temannya dan hasilnya diserahkan ke guru. 
h. Bagi kelompok yang sudah presentasi dengan guru wajib menjelaskan ke 4 kelompok lainya secara bergantian. (take and give), dan masing-masing anggota dapat menjadi pemandu untuk kelompok lain.

i. Diadakan evaluasi secara tertulis untuk mengetahui tingkat pemahaman peserta didik.

\section{Pengamatan.}

Pada pelaksanaan siklus II ini pembelajaran dilaksanakan dalam $6 \times$ pertemuan, $2 x$ pertemuan untuk persiapan pembuatan display kosakata bentuk noun, 3 untuk pembelajaran, dan I $x$ pertemuan untuk tes tulis. Pada siklus ke II ini diperoleh data nilai tes tulis di atas KKM sebanyak 28 dari 34 peserta didik atau (82\%) tampak adanya peningkatan nilai pada hasil tes tulis sebesar $(32 \%)$.

Tabel 2. Hasil post-test

\begin{tabular}{lll}
\hline Jumlah Siswa & $\begin{array}{l}\text { Di bawah } \\
\text { KKM }\end{array}$ & Di atas KKM \\
\hline 34 & 6 & 28 \\
\hline
\end{tabular}

*Nilai $\mathrm{KKM}=70$

\section{Refleksi}

Dari hasil pengamatan yang dilakukan selama pelaksanaan siklus II, penulis melihat adanya perubahan-perubahan yang positif pada peserta didik di antaranya adalah

a. Peserta didik belajar dalam kondisi menyenangkan.

b. Peserta sangat antusias selama pelaksanaan pembelajaran.

c. Adanya peningkatan penguasaan kosakata yang cukup signifikan.

d. Peserta didik dapat menyebutkan kosakata bentuk noun tanpa banyak kesalahan yang berarti.

e. Peserta didik dapat menulis kosakata bentuk noun tanpa ada kesalahan lagi.

\section{Pembahasan}

Dibutuhkan guru yang inovatif untuk membangkitkan minat peserta didik pada pembelajaran Bahasa Inggris, karena meski sudah ada tayangan video apabila hanya di dominasi oleh guru selama proses pembelajaran, peserta didik menjadi kurang antusias.

Model Pembelajaran STW (See, Talk, Write) adalah salah satu model pembelajaran yang melibatkan sisi psikis maupun motorik peserta didik. Dari mengamati melafalkan hingga menulis ulang apa yang mereka ucapkan, model STW ini tentu memotivasi peserta didik dan sangat diperlukan dalam rangkaian Belajar Bahasa Inggris khususnya Penguasaan Kosakata Bentuk Noun.

Pada penelitian ini penulis juga menggunakan media gambar yang mereka buat sendiri untuk mempermudah penguasaan kosakata bentuk noun. Media gambar merupakan media yang cukup efektif untuk digunakan dalam pembelajaran Bahasa Inggris sebagai Bahasa asing, media gambar adalah media yang paling umum dipakai. Hal ini dikarenakan peserta didik lebih menyukai gambar daripada tulisan, apalagi jika gambar dibuat dan disajikan dengan persyaratan yang baik. Gambar-gambar ini dapat menambah semangat peserta didik dalam mengikuti proses pembelajaran.

\section{Kesimpulan}

Berdasarkan pelaksanaan kegiatan yang dilakukan mulai dari siklus I dan siklus II diperoleh simpulan bahwa metode STW (See, Talk, Write) terbukti dapat meningkatkan penguasaan kosakata Bahasa Inggris pada peserta didik di kelas 7D SMP Negeri 2 Pasuruan.

\section{Saran}

Saran bagi penelitian berikutnya adalah menggunakan gambar versi digital dengan pelaksanaan tetap dalam kelompok-kelompok 
kecil. Hal tersebut untuk mengetahui apakah antara media gambar versi cetak dengan digital memiliki pengaruh yang berbeda pada peningkatan penguasaan kosakata bentuk noun.

\section{Daftar Pustaka}

Farkhana. (2016). Penggunaan Model Think Talk Write (Ttw) Dengan Media Booklet Pada Hasil Belajar Siswa Materi Invertebrata Di Sma Negeri 2 Ungaran [UNIVERSITAS NEGERI SEMARANG]. https://doi.org/10.15294/jbe.v6i1.14056

Fauziah, L. (2011). The Effectiveness of Teaching Vocabulary Using Picture. Syarif Hidayatullah State Islamic University.

Narmaditya, B., Winarning, W., \& Wulandari, D. (2017). Impact of Problem-Based Learning on Student Achievement in Economics Course. Classroom Action Research Journal, 1(1), 1-11. https://doi.org/10.17977/um013v1i1201 $7 \mathrm{p} 001$

Rohman, I. M. (2016). THE EFFECTIVENESS OF USING PICTURES IN TEACHING VOCABULARY (An Experimental Research at the Seventh Grade of SMP Hasanuddin 5 Semarang in the Academic Year of 2016/2017). WALISONGO STATE ISLAMIC UNIVERSITY SEMARANG.

Yussa, V. Y. (2012). An Analysis of the Student's Vocabulary Mastery at the Second Year Students of SMPN 8 Kotabumi. STKIP Muhammadiyah. 